DE

M E D I C I N A

T R O P I C A L

$\mathrm{DE}$

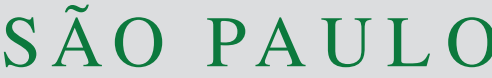

JOURNAL OF THE SÃO PAULO INSTITUTE OF TROPICAL MEDICINE

${ }^{1}$ Universidade Estadual de Montes Claros, Montes Claros, Minas Gerais, Brazil

${ }^{2}$ Centro de Controle de Zoonoses, Montes Claros, Minas Gerais, Brazil

${ }^{3}$ Fundação Oswaldo Cruz, Instituto René Rachou, Laboratório de Esquistossomose, Belo Horizonte, Minas Gerais, Brazil

${ }^{4}$ Fundação Oswaldo Cruz, Instituto René Rachou, Laboratório de Pesquisa Clínica, Belo Horizonte, Minas Gerais, Brazil

${ }^{5}$ Instituto Evandro Chagas, Ananindeua, Pará, Brazil

Correspondence to: Nídia Francisca de Figueiredo Carneiro Universidade Estadual de Montes Claros, Centro de Ciências Biológicas e da Saúde, Departamento de Saúde Mental e Saúde Coletiva, Av. Rui Braga, s/n, Caixa Postal 13, Campos Universitário Darcy Ribeiro, CEP 39.401-089, Montes Claros, MG, Brazil.

Tel: +55 3832298282

E-mail: nidiaffc@gmail.com

Received: 2 May 2019

Accepted: 22 October 2019

\section{Transmission control of schistosomiasis mansoni in a low endemicity area through a single intervention with rigorous prospection of infected cases treated with praziquantel: evaluation after 7 years of intervention}

\author{
Nídia Francisca de Figueiredo Carneiro ${ }^{1,2}$, Antônio Prates Caldeira ${ }^{\circledR 1}$, \\ Naftale Katz ${ }^{\circledR 3}$, Áureo Almeida de Oliveira ${ }^{\circledR 3}$, Liliane Maria Vidal Siqueira ${ }^{\left({ }^{1} 3\right.}$, \\ Edward Oliveira ${ }^{(4}$, Marise Fagundes Silveira ${ }^{\circledR}$, Martin Johannes Enk ${ }^{(5}$, \\ Paulo Marcos Zech Coelho 3
}

\section{ABSTRACT}

A prospective cohort study with rigorous searching for schistosomiasis cases was conducted among residents of Pedra Preta, Montes Claros, Minas Gerais State, Brazil, seven years after an intervention. Kato-Katz (KK), Saline Gradient, Miracidia Hatch and Polymerase Chain Reaction (PCR) were used as the diagnostic methods in 2008. In the period of 2013-2016, 175 patients remaining in the area were examined using the diagnostic methods Kato-Katz ( 24 slides, $1 \mathrm{~g}$ of feces) and Saline Gradient ( 2 procedures, $1 \mathrm{~g}$ of feces). Sixty-eight out of the 69 infected and treated individuals in 2008 tested negative. The percentage of new cases was $2.29 \%$ (4/175), and the 4 infected individuals presented low parasitic load [1, 6, 7 and 19 eggs per gram (EPG)]. All the participants answered epidemiological questionnaires on risky behavior. All residences had pit latrines and domiciliary water supply. The primary transmission focus (lake) was dry for several months. Malacological surveys showed a few non-infected specimens of Biomphalaria glabrata. A clear dominance of Biomphalaria straminea was observed. It can be inferred that a significant decrease in the disease transmission occurred after a single action through an intense search for infected and treated cases under the ecoepidemiological conditions of this area.

KEYWORDS: Schistosoma mansoni. Schistosomiais. Transmission control. Percentage of new cases. Control. Low transmission area. Brazil.

\section{INTRODUCTION}

Schistosomiasis is a disease caused by a digenea trematode accounting for over 240 million people infected in 78 countries, in which 779 million people are at risk of infection, 120 millions have clinical symptoms ${ }^{1}$ and 20 millions have severe disease ${ }^{2}$.

Approximately 120 million people exhibit risky behavior, inhabiting irrigation areas and banks of water bodies and dams in tropical and subtropical areas. Schistosomiasis is considered by the World Health Organization (WHO) as one of the most important parasitosis affecting humans with consequent socioeconomic impact ${ }^{3}$.

Following the implementation of disease control programs in the last four decades associated with socioeconomic and sanitation measures, The Brazilian Ministry of Heath measures have drastically reduced the need of hospital admission from 1,314 to 200 between 1998 and 2016 with annual death average was 508 between 2006 and $2015^{4}$. 
A recent national survey carried out in Brazil has revealed that the proportion of individuals infected with Schistosoma mansoni is $0.99 \%$. This survey involved 197,564 school-children aged 7 to 17 years, analyzing Kato-Katz slides from a single feces sample, in all 26 Brazilian States and the Federal District ${ }^{5}$.

Considering that the Kato-Katz method (2 slides per sample) is considered to significantly underestimate the real disease prevalence ${ }^{6-11}$, it can be presumed that the prevalence is currently around 3 to 4 million individuals ${ }^{12}$.

The Schistosomiasis Control Program of Montes Claros (PCE-MOC) used 1 Kato-Katz slide per sample ${ }^{13}$ between 2001 and 2004 and 2 slides after 2004 in 357 rural areas, except in Pedra Preta. Based on the results, periodic treatments with praziquantel were carried out in the risk areas (> 5\% prevalence). All risk areas are still monitored and reexamined until the reduction in prevalence is below $5 \%$. The permanence of low prevalences underestimated by the Kato-Katz (1 slide per sample) method was observed, making it difficult to achieve the eradication of the disease, even in settings with treated water supply, proper waste disposal and health education guidelines. In 2008, the population of Pedra Preta underwent a rigorous infection detection process and the infected inhabitants were treated with praziquantel, and followedby rigorous cure control 30 , 90 and 180 days after treatment ${ }^{9}$.

The Kato-Katz diagnostic technique ${ }^{13}$ is considered the preferred method for the diagnosis in epidemiological survey settings, and in control programs because it is simple, quantitative, unexpensive and easy to perform according to the $\mathrm{WHO}^{1,14}$. However, its low sensitivity in low endemic settings ${ }^{8,9,15}$ has increased the number of slides required per sample ${ }^{7,9}$. Therefore, in the present study, 24 Kato-Katz slides ( $1 \mathrm{~g}$ of feces) were examined and two Saline Gradient ${ }^{16}$ procedures were performed as well.

The aim of the present prospective cohort study was to evaluate, after 7 years, the effects of the treatment with praziquantel performed in 2008 , by reexamining all individuals through a rigorous prospection of infection cases by means of parasitological quantitative feces exams. In addition, information regarding sanitation and eco-epidemiological factors related to the schistosomiasis transmission in the area during the period was analyzed.

\section{MATERIALS AND METHODS}

\section{Study area and population}

This is a prospective cohort study carried out from 2013 to 2016 in Pedra Preta, a community of Montes Claros, Minas Gerais State (MG), Brazil, where there is a lake created by the damming of the Buriti Seco river, and Riachao river located $8 \mathrm{~km}$ away from the community. The municipality economy is based on agriculture, mainly of beef cattle. The population was examined in 2008 and from this population, 175 habitants that remained in the area were included in the present study.

\section{Inclusion criteria}

Individuals who participated in the 2008 research that still lived in the area, or returning weekly or biweekly to the area due to family ties, and new residents (over one year of age).

\section{Diagnostic methods}

One feces sample was collected on an annual basis using an $80 \mathrm{~mL}$ white plastic collector with a screw cap, properly labeled with each participants' full name, registration number, survey number and date of collection. The samples were delivered by the community at the Basic Health Unit of Pedra Preta and taken in refrigerated boxes to the field laboratory located in Tabuas, where they were processed for further examination.

\section{Kato-Katz ${ }^{\circledR}$ method $^{13}$}

Twenty-four slides were prepared corresponding to $1 \mathrm{~g}$ of feces $(24 \times 41.7 \mathrm{mg} \pm 1 \mathrm{~g}$ ) per individual. The 24 slides were divided into 1-8, 9-16 and 17-24 aliquots. Each group was under the responsibility of a laboratory technician with 32 years of experience and two technicians with 25 years of experience, employees of the Schistosomiasis Control Program of Montes Claros (Centro de Controle de Zoonoses de Montes Claros - CCZ-MOC).

\section{Saline gradient method ${ }^{\circledR 16}$}

Two feces samples (500 $\mathrm{mg}$ each) from each participant were simultaneously examined, totalizing $1 \mathrm{~g}$ of feces. The excess of liquid was removed and the remaining portion with sediment $(2 \mathrm{~mL})$ was transferred to a $10 \mathrm{~mL}$ plastic tube, and $2 \mathrm{~mL}$ of $20 \%$ formaldehyde solution. All sediment was examined under microscopy and S. mansoni eggs were counted.

\section{Clinical examination and treatment}

All the patients were examined by a physician and treated with a single dose of Praziquantel ${ }^{\circledR}$ - PZQ (Farmanguinhos), $50 \mathrm{mg} / \mathrm{kg}$ for adults and $60 \mathrm{mg} / \mathrm{kg}$ for 
children. The drug was administered after a meal (French bread sandwich with mortadella, accompanied by a fruit juice or mineral water) to allow a better drug absorption ${ }^{17}$. Clinical data and information regarding the risk of contact with natural water were recorded in the medical notes and epidemiological/socio-demographic questionnaires were answered by the patients or their legal guardians. Individuals that were positive for other intestinal parasites were treated according to the identified species, following the recommendations of the Brazilian Ministry of Health.

\section{Cure control}

Feces samples from treated patients were examined after 30, 90 and 180 days after treatment using the Kato-Katz (24 slides) and the Saline gradient (two $500 \mathrm{mg}$ samples) methods.

\section{Epidemiologic and sociodemographic questionnaires}

The sociodemographic and epidemiological questionnaires ${ }^{18}$, consisting of objective questions were applied to all participating families. The following data were collected: name, age, sex, occupation, schooling, work place, water source, waste disposal, physical characteristics of housing construction and the degree of contact with natural water bodies.

\section{Geographic information system}

Population contact points with natural water bodies containing snails and residences of all participants that were positive and negative for S. mansoni were georeferenced.

\section{Malacological research}

Eight equidistant $(10 \mathrm{~m})$ collection points were marked with wood piles at the dam of Pedra Preta Lake, and 17 along the banks of the Riachao River. Snails of the genus Biomphalaria were sought and collected in 2013, 2014 (January, April and September), 2015 (January, May and September) and 2016 (January and March), using a metal ladle specific for capturing snails, with wooden handle and a $25 \mathrm{~cm}$ long straight clamp with fine tips, placed in $1 \mathrm{~kg}$ transparent plastic bags with water from their own water body and vegetation to feed them. The bags were identified with date and the collection point number, carefully placed in a styrofoam box and transported to the CCZ-MOC laboratory, where they were packaged. Then they were sent to the Rene Rachou Institute (IRR) laboratories where they were identified according to Paraense ${ }^{19}$ and diagnosed by the PCR method ${ }^{20,21}$. Other samples from the same collection were also examined at the CCZ-MOC laboratory by crushing the specimens between glass plates in order to detect infection by $S$. mansoni.

\section{Health education}

After agreeing to participate in the study, the population of Pedra Preta was provided with further information concerning the research design and a lecture about schistosomiasis with emphasis on the parasite life cycle, transmission routes and health consequences for the infected individual. The population received information leaflets on the parasite life cycle and prevention measures. Subsequent to the identification of the parasites in this population, interactive activities were performed in five classrooms with students aged 7 to 16, residents of Pedra Preta and neighboring localities, who attended the same classes at Escola Municipal Caio Lafeta (a public school), located in the district of Ermidinha. At the end of the activities, the students were given A4 sheets of paper and crayons and were asked to draw and write what they had learned about the cycle of schistosomiasis transmission and how they might become infected in their environment. Educational material, with pictures and accessible language on all parasites found in the studied population was developed for further distribution to the population of Pedra Preta ${ }^{22}$.

\section{Ethical consideration}

The study protocol was approved by the Human Research Ethics Committee at the Rene Rachou Institute/ Oswaldo Cruz Foundation (CEPSH 03/2008). All the participants and parents/legal guardians were informed about the objective and procedures of the study and signed a written informed consent. Samples were coded and the results were confidentially treated. All the participants found positive for $S$. mansoni or other intestinal helminths were clinically examined by a physician and treated.

\section{RESULTS}

\section{Study area and population}

There were 103 buildings in Pedra Preta (98 residences, 1 Health Basic Unit - HBU, 1 cemetery and 2 churches). From a total of 98 residences, 27 were uninhabited and 6 were closed. Thirteen individuals ( 9 men and 4 women) refused to participate in the research, including a family of 4 members. Other 7 individuals ( 4 men and 3 women) could not participate for various reasons namely, lived in 
Montes Claros, worked elsewhere, believed that the exam included only positive individuals identified in 2008-2009 and infants $(<1$ year). A total of 20 individuals did not participate. The study population was comprised of the individuals who participated in the 2008-2009 research (population 1), born after 2007 and all those currently living in the area. Sixty-eight out of the 69 positive individuals identified and studied in 2008-2009 were reexamined in the 2013 and 2014 surveys. One hundred and seventy-five individuals from population 1 were included in the 2013 and 2014 surveys and 19 individuals did not participate for two reasons, namely 11 moved to Montes Claros and 8 died. Twenty-eight new participants were included being 12 born in Pedra Preta between 2007 and 2012, 3 lived in Pedra Preta, but did not participate in research 1; 11 worked in another locality and 2 women who were pregnant at the time of the treatment. One of the two pregnant women tested positive for $S$. mansoni in 2008-2009, but the treatment was contraindicated. All new participants were residents of Pedra Preta. It is worth mentioning that 68 out of the 69 individuals who were positive and treated for S. mansoni in 2008-2009 tested negative. The 12 children born between 2008 and 2016 were negative as well.

The classification of the housing showed that $99 \%$ were brick constructions with plastered and painted walls (inside and outside), covered with roof tiles, ceramic flooring, sanitary facilities with shower, toilet and a sink with covered septic tank. All residences received piped well water.

The contact with natural water body was reported by $80.6 \%$ (141/175) being $54.9 \%$ (96/175) due to the need to cross the dam at rainy seasons and $45.7 \%$ (80/175) for recreational reasons.

The population's occupations were divided, as follows: $24 \%$ (42/175) were rural workers, $20 \%$ (35/175) students, $19.4 \%$ (34/175) qualified workers, $17.7 \%$ (31/175) housewives, $10.9 \%(19 / 175)$ retired, $2.9 \%(5 / 175)$ rural producers, $2.3 \%$ (4/175) shopkeepers, $1.7 \%$ (3/175) unemployed and $1.1 \%(2 / 175)$ washerwomen.

The predominant schooling levels were: $38.9 \%(68 / 175)$ incomplete elementary school education, $13.1 \%(23 / 175)$ complete elementary school education, $20 \%(35 / 175)$ complete high school education, $11.4 \%$ (20/175) incomplete high school education, $4.0 \%$ (7/175) pre-school education, $5.7 \%(10 / 175)$ higher education, and 6.9\% (12/175) were illiterate.

Regarding the snails species found at the primary transmission focus (lake), specimens of Biomphalaria glabrata, the main intermediate host of schistosomiasis, were found in five collection points in 2013 and four in 2014. In 2015-2016 no specimens were found. In 2013-2014, specimens Biomphalaria straminea were found in one point and in 2015-2016 it was the only species found in all the points.

\section{Clinical exam of the 4 infected patients}

Clinical examination performed by an experienced physician showed that all subjects had no clinical manifestation or complaints, although occasional episodes of nonspecific abdominal pain and/or diarrhea were reported. All of them had low parasitic loads $(1,6,7,19$ EPG). This clinical presentation is compatible with the intestinal form of schistosomiasis ${ }^{1}$.

Data analysis of the 4 infected patients detected in the last intervention who remained in the area during the considered observation period

The four patients that presented $S$. mansoni eggs in their stools in 2013 were negative in the previous evaluation (2008).

\section{DISCUSSION}

The experimental design of the present study (Figure 1) was developed to allow the detection of almost all infected individuals through an extensive and intense process of case search using the Kato-Katz (24 slides) and 2 Saline Gradient procedures. The Saline Gradient technique, has already been validated in previous studies and showed to be practical and sensitive for this type of approach ${ }^{16}$. Twenty-four (24) slides Kato-Katz ( $1 \mathrm{~g}$ of feces) and 2 Saline Gradient procedures ( $1 \mathrm{~g}$ of feces) were used totaling 48 Kato-Katz slides for each patient. This methodology was applied in the cure control period (30, 90 and 180 days after treatment), in the 2013 and 2014 survey. In the cure control period, a total of 144 Kato-Katz slides ( $6 \mathrm{~g}$ of feces per patient) were prepared and examined.

From 2013 to 2016, the PCR diagnosis method was not used as it requires more complex laboratory structure and has a high $\operatorname{cost}^{9}$.

A prospective study with such rigor on the searching of infection cases and cure control after treatment has not been carried out in any other schistosomiasis transmission region. The results obtained here show that this approach, which unquestionably demands a lot of work mainly due to the enormous amount of exams required, can detect people with low infection level. The unquestionable benefit of treating almost all infected individuals in a short time period through a single intervention may result in the interruption or a significant decrease in the schistosomiasis transmission, which would be highly compensatory and desirable. 


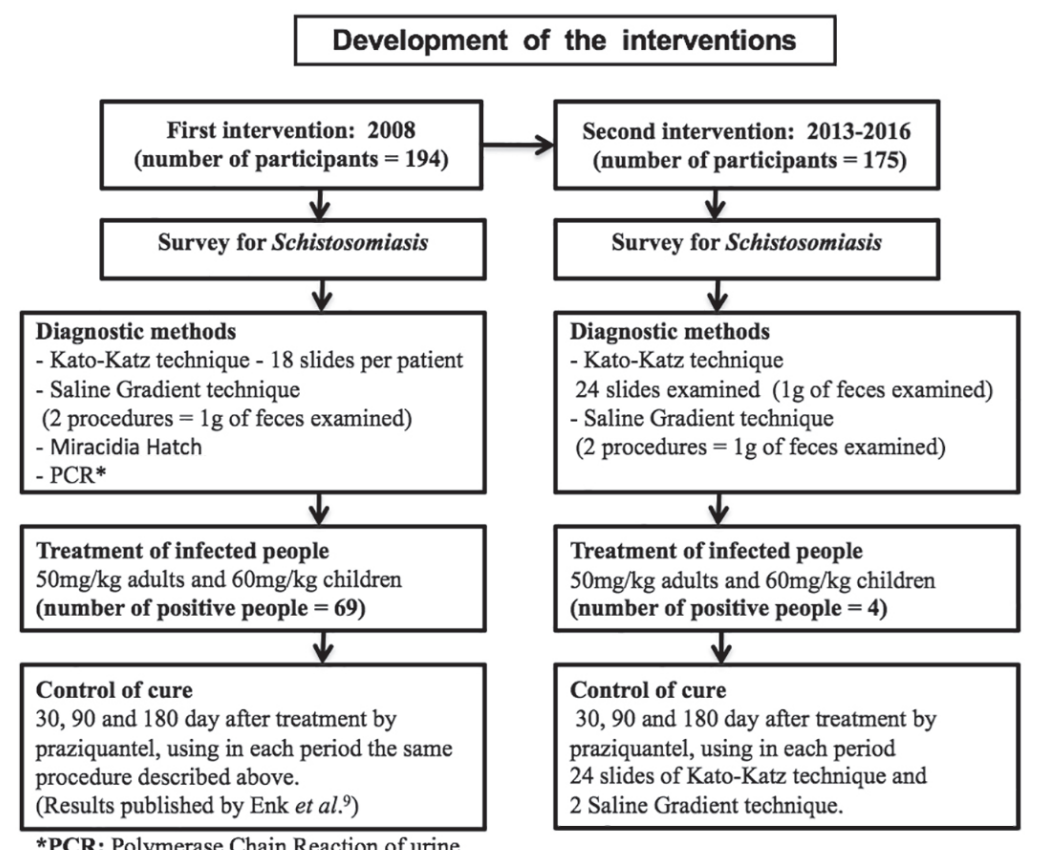

Figure 1 - Development of the interventions to detect the percentage of new cases of schistosomiasis in Pedra Preta - Brazil.

The 175 residents who participated in the first intervention and continued to live in the area, and therefore remained at risk of infection or reinfection in a period of 5 years until the second treatment, were the natural control group in this study.

For ethical and medical reasons, all residents of the area (203), not only the 175 considered in the study, were diagnosed and treated for the helminths found in the exams (S. mansoni and soil transmitted helminths). Among the 28 new participants, 4 were positive for $S$. mansoni presenting 2, 3, 8 and 138 eggs per gram of feces. Clinical examination showed that all infected patients had the intestinal form of the disease.

None of the 68 individuals infected and treated in the first intervention (2008) who continued having contact with natural water bodies $(66.2 \%)$ was re-infected, despite the search through two thoroughly performed parasitological exams. The 4 individuals who tested positive in the first intervention were negative, which may be explained by their very low parasitic loads (1, 6, 7 and $19 \mathrm{EPG}$ ) leading to false-negative results or they became infected later on in this area.

The specific conditions of the area show that all the houses have septic tanks and water supply derived from a pipe well. The climate conditions in the period were marked by a 7-year severe drought with consequent total loss of water in the main schistosomiasis infection source, a small dam or lake near the community ( 850 meters). The lake remained dry in most months of the years considered in the study.
Specimens of B. glabrata were collected at the eight points selected on the lake and some were found to eliminate S. mansoni cercariae. Between 2013 and 2016 there was an atypical drought in the region resulting in lake drying with the average maximum temperature reaching $35.5^{\circ} \mathrm{C}^{23}$ and annual average rainfalls of 104.56, 39.89, 39.20 and 69.9, respectively. Specimens of $B$. glabrata were not found in monthly collections, but specimens of $B$. straminea were found in some of the collection months (Figure 2).

It is important to note that in an area similar to Pedra Preta named Tabuas, the same methodological procedure was used and 90 days after treatment of the schistosomiasis patients, 8 out of 40 individuals were re-infected. The infection source of that area was a stream with a waterfall contaminated by sewage from other communities located upstream (Unpublished data from the authors).

These observations reminded us that each schistosomiasis transmission focus presents peculiar characteristics that make it unique and that comprehensive control measures cannot be generalized without considering the socioeconomical, sanitary and eco-epidemiological characteristics inherent to each site. This reflections are extremely important at the present moment as the elimination of schistosomiasis in the American continent by 2020 and in Africa by 2025 is an ambitious goal established by the $\mathrm{WHO}^{1}$.

Finally, well-established basic measures such as sanitary education, sanitation (with water and sewage treatment) and treatment of individuals will benefit the population. Not only schistosomiasis, but about fourteen other diseases (e.g. hepatitis and gastroenteritis) that result from inadequate 


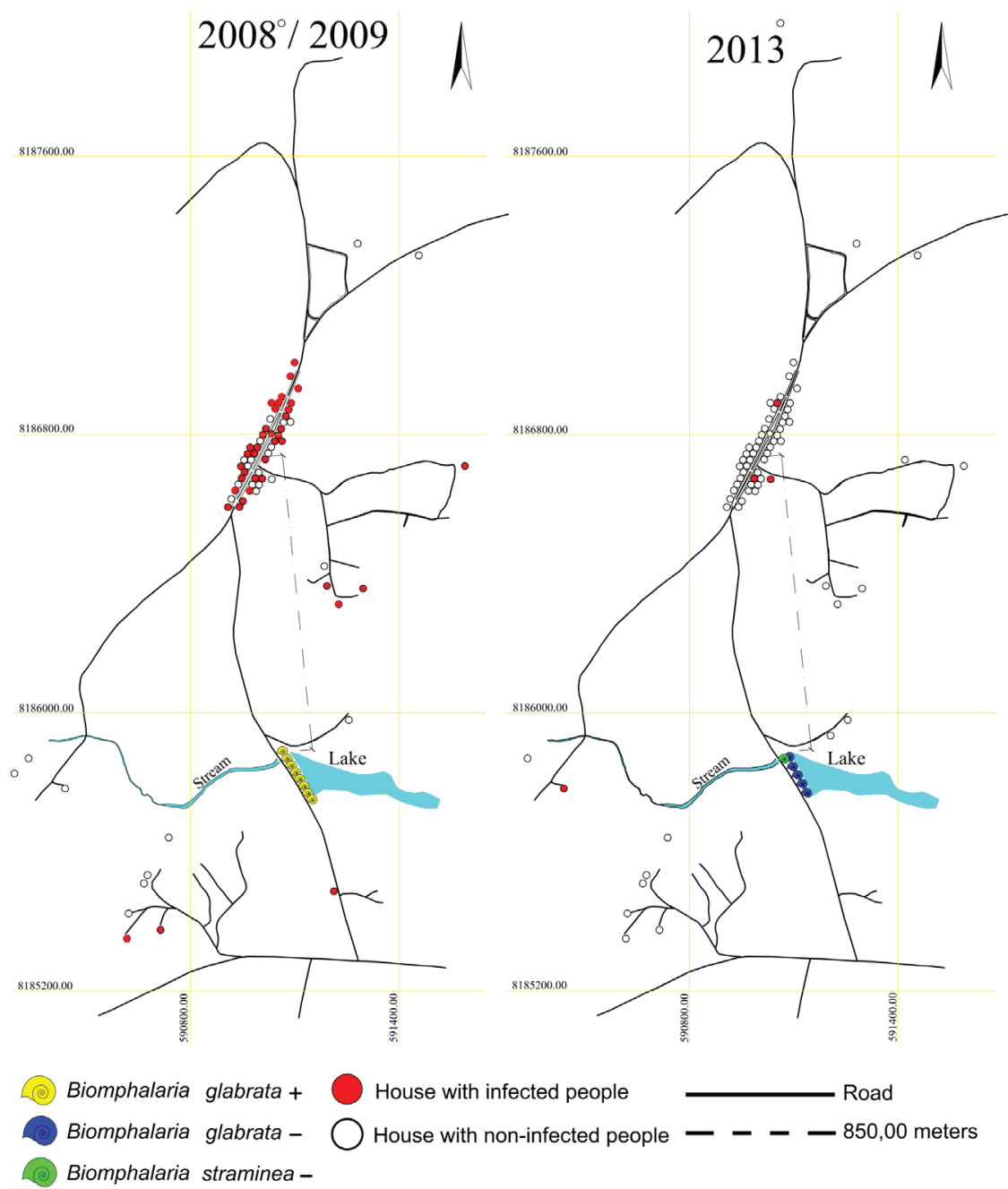

Figure 2 - Geographical location of the participants' houses (infected or not), the transmission focus (lake) and the distance between the houses and the lake in Pedra Preta - Brazil.

sanitary conditions and lack of health education may be controlled.

\section{ACKNOWLEDGMENTS}

To the population of Pedra Preta for their participation, to the teams of Schistosomiasis Laboratory at the Rene Rachou Research Center, Oswaldo Cruz Foundation (Fiocruz), Belo Horizonte, Minas Gerais, Brazil and Program of Control of Schistosomiasis - PCE of Zoonosis Control Center, Montes Claros, MG, Brazil for their commitment to the research and to all the employees, who in some way, collaborated to this research.

\section{AUTHORS' CONTRIBUTIONS}

NFFC: participated in all stages of laboratory research, interviews, Geoprocessing, collection and examination of Biomphalaria snails, lectures on the schistosomiasis disease for children/teenagers of the community, in the period 2013- 2016; AAO and NFFC: developed the laboratory techniques Kato-Katz and Saline Gradient; PMZC, APC and NK: were the supervisor and co-supervisor of the research from the study design; MFS: contributed to statistical analyses; EO: performed the PCR-Elisa technique at the Fiocruz laboratory in Belo Horizonte in the 2008 and 2013-2014 researches; AAO, LMVS and MJE: conducted the 2008 research with the study population, Geoprocessing, collection and examination of Biomphalaria snails.

\section{CONFLICT OF INTERESTS}

All the authors have none to declare.

\section{FINANCIAL SUPPORT}

This research had financial support from the Schistosomiasis Laboratory at the Rene Rachou Research 
Center, Oswaldo Cruz Foundation (Fiocruz), Belo Horizonte, Minas Gerais, Brazil from 2013 to 2016; Zoonoses Control Center in Montes Claros, Minas Gerais, Brazil from 2013 to 2016, as well as local resources.

\section{REFERENCES}

1. World Health Organization. Schistosomiasis: epidemiological situation. [cited 2019 Nov 8]. Available from: http://www. who.int/schistosomiasis/epidemiology/en/

2. Chitsulo L, Engels D, Montresor A, Savioli L. The global status of schistosomiasis and its control. Acta Trop. 2000;77:41-51.

3. Brasil. Ministério da Saúde. Secretaria de Vigilância em Saúde. Departamento de Vigilância das Doenças Transmissíveis. Vigilância da esquistossomose mansoni: diretrizes técnicas. $4^{\text {a }}$ ed. Brasília: Ministério da Saúde; 2014. [cited 2019 Nov 8]. Available from: http://bvsms.saude.gov.br/bvs/publicacoes/ vigilancia_esquistossome_mansoni_diretrizes_tecnicas.pdf

4. Brasil. Ministério da Saúde. DATASUS. Mortalidade: Brasil. [cited 2019 Nov 8] Available from: http://portalarquivos2.saude.gov. br/images/pdf/2016/julho/11/obitos-esquistossomose.pdf

5. Katz N. Inquérito nacional de prevalência da esquistossomose mansoni e geo-helmintoses. Belo Horizonte: CPqRR; 2018. [cited 2019 Nov 8]. Available from: https://www.arca.fiocruz. $\mathrm{br} /$ handle/icict $/ 25662$

6. de Vlas SJ, Gryseels B. Underestimation of Schistosoma mansoni prevalences. Parasitol Today. 1992;8:274-7.

7. Enk MJ, Lima AC, Drummond SC, Schall VT, Coelho PM. The impact of the number of stool samples on the prevalence, the infection intensity and the distribution of the infection with Schistosoma mansoni among a population in an area of low transmission. Acta Trop. 2008;108:222-8.

8. Siqueira LM, Coelho PM, Oliveira AA, Massara CL, Carneiro $\mathrm{NF}$, Lima AC, et al. Evaluation of two coproscopic techniques for the diagnosis of schistosomiasis in a lowtransmission area in the state of Minas Gerais, Brazil. Mem Inst Oswaldo Cruz. 2011;106:844-50.

9. Enk MJ, Oliveira e Silva G, Rodrigues NB. Diagnostic accuracy and applicability of a PCR system for the detection of Schistosoma mansoni DNA in human urine samples from an endemic area. PLoS One. 2012;7:e38947.

10. Grenfell R, Harn DA, Tundup S, Da'dara A, Siqueira L, Coelho PM. New approaches with different types of circulating cathodic antigen for the diagnosis of patients with Low Schistosoma mansoni load. PloS Negl Trop Dis. 2013;7:e2054.

11. Siqueira LM, Couto FF, Taboada D, Oliveira AA, Carneiro NF, Oliveira E, et al. Performance of POC-CCA ${ }^{\circledR}$ in diagnosis of schistosomiasis mansoni in individuals with low parasite burden. Rev Soc Bras Med Trop. 2016;49:341-7.
12. Katz N, Rocha RS, Barbosa C, Bezerra FS, Coelho PMZ, Carvalho OS, et al. National survey on Schistosomiasis mansoni and Geohelminths in Brazil (2011-2014). 12 ${ }^{\text {th }}$ International Congress of Parasitology - ICOPA. August 10-15. Mexico City; 2014.

13. Katz N, Chaves A, Pellegrino J. A Simple device for quantitative stool thick-smear technique in schistosomiasis mansoni. Rev Inst Med Trop Sao Paulo. 1972;14:397-400.

14. World Health Organization. The control of schistosomiasis: second report of the WHO Expert Committee. Geneva: WHO; 1993. [cited 2019 Nov 8]. Available from: https://apps.who. int/iris/handle/10665/37115

15. Lin DD, Liu JX, Liu YM, Hu F, Zhang YY, Xu JM, et al. Routine Kato-Katz technique underestimates the prevalence of Schistosoma japonicum: a case study in an endemic area of the People's Republic of China. Parasitol Int. 2008;57:281-6.

16. Coelho PM, Jurberg AD, Oliveira AA, Katz N. Use of a saline gradient for the diagnosis of schistosomiasis. Mem Inst Oswaldo Cruz. 2009;104:720-3.

17. World Health Organization. Prevention and control of schistosomiasis and soil-transmitted helminthiasis: report of the WHO Expert Committee. Geneva: WHO; 2002. [cited 2019 Nov 8]. Available from: https://apps.who.int/iris/ handle/10665/42588

18. Costa MF, Rocha RS, Magalhães MH, Katz N. Um modelo hierárquico de análise das variáveis sócio-econômicas e dos padrões de contatos com águas associados à forma hepatoesplênica da esquistossomose. Cad Saude Publica. 1994;10:241-53.

19. Paraense WL. Estudo atual da sistemática dos planorbídeos brasileiros. Arq Mus Nac. 1975;55:105-28.

20. Gomes LI, Marques LH, Enk MJ, Coelho PM, Rabello A. Further evaluation of an updated PCR assay for the detection of Schistosoma mansoni DNA in human stool samples. Mem Inst Oswaldo Cruz. 2009;104:1194-6.

21. Caldeira RL, Jannotti-Passos LK, Carvalho OS. Molecular epidemiology of Brazilian Biomphalaria: a review of the identification of species and the detection of infected snails. Acta Trop. 2009;111:1-6.

22. Carneiro NF, organizadora. Esquistossomose mansoni e outras helmintoses: Comunidade Pedra Preta. Montes Claros: Henriques Design; 2017.

23. Minas Gerais. Centro de Estudos de Convivência com o Semiárido. Dados meteorológicos mensais e anuais. [cited 2019 Nov 19]. Available from: http://www.cecs.unimontes.br/index.php/pt/ dados-meteorologicos/374-dados-meteorologicos-mensaise-anuais-organizados-pelo-cecs 